\title{
Building Retrofit and Energy Conservation/Efficiency Review: A Techno-Environ-Economic Assessment of Heat Pump System Retrofit in Housing Stock
}

\author{
Mustapha Mukhtar ${ }^{1}\left(\mathbb{D}\right.$, Bismark Ameyaw $^{2}{ }^{\circledR}$, Nasser Yimen ${ }^{3}\left(\mathbb{D}\right.$, Quixin Zhang ${ }^{1}$, Olusola Bamisile ${ }^{4, *}$, \\ Humphrey Adun ${ }^{5}$ and Mustafa Dagbasi ${ }^{5}$ \\ 1 School of Economics and Management, Guangdong University of Petrochemical Technology, \\ Maoming 525000, China; mustaphamukhtar@ymail.com (M.M.); gggnix@163.com (Q.Z.) \\ 2 School of Management and Economics, University of Electronic Science and Technology of China, \\ Chengdu 610054, China; 201714110101@std.uestc.edu.cn \\ 3 National Advanced School of Engineering, University of Yaounde I, Yaounde, Cameroon; nazerois@yahoo.fr \\ 4 School of Mechanical and Electrical Engineering, University of Electronic Science and Technology of China, \\ Chengdu 610054, China \\ 5 Energy Systems Engineering Department, Cyprus International University, Haspolat-Lefkosa 99258, Turkey; \\ hadun@ciu.edu.tr (H.A.); mdagbasi@ciu.edu.tr (M.D.) \\ * Correspondence: Boomfem@hotmail.com
}

check for updates

Citation: Mukhtar, M.; Ameyaw, B.; Yimen, N.; Zhang, Q.; Bamisile, O.; Adun, H.; Dagbasi, M. Building Retrofit and Energy Conservation/ Efficiency Review: A Techno-EnvironEconomic Assessment of Heat Pump System Retrofit in Housing Stock. Sustainability 2021, 13, 983. https://doi.org/10.3390/su13020983

Received: 2 December 2020

Accepted: 13 January 2021

Published: 19 January 2021

Publisher's Note: MDPI stays neutral with regard to jurisdictional claims in published maps and institutional affiliations.

Copyright: (c) 2021 by the authors. Licensee MDPI, Basel, Switzerland. This article is an open access article distributed under the terms and conditions of the Creative Commons Attribution (CC BY) license (https:// creativecommons.org/licenses/by/ $4.0 /)$.

\begin{abstract}
The world has not been able to achieve minimum greenhouse gas emissions in buildings' energy consumptions because the energy and emissions optimization techniques have not been fully utilized. Thermal comfort is one of the most important issues for both residential and commercial buildings. Out of the $40 \%$ of global energy consumed by buildings, a large fraction is used to maintain their thermal comfort. In this study, a comprehensive review of the recent advancements in building energy conservation and efficiency application is presented based on existing high-quality research papers. Additionally, the retrofit of the heating/cooling and hot water system for an entire community in Cyprus is presented. This study aims to analyze the technical and environmental benefits of replacing existing electric heaters for hot water with heat pump water heating systems and the use of heat pump air conditioners for thermal comfort in place of the existing ordinary air conditioners for space heating and cooling. One administrative building, 86 apartments (including residential and commercial) buildings, and a restaurant building is retrofitted, and the feasibility of the project is determined based on three economic indicators, namely; simple payback period (SPP), internal rate of return (IRR), and net present value $(N P V)$. The electrical energy required by the hot water systems and the heating/cooling system is reduced by $263,564 \mathrm{kWh} / \mathrm{yr}$ and $144,825 \mathrm{kWh} / \mathrm{yr}$, respectively. Additionally, the retrofit project will reduce Cyprus' $\mathrm{CO}_{2}$ emission by $121,592.8 \mathrm{~kg}$ yearly. The $S P P, I R R$, and NPV for the project show that the retrofit is economically feasible.
\end{abstract}

Keywords: energy conservation; energy efficiency; retrofit; review; techno-economic analysis

\section{Introduction}

The emission of greenhouse gases into the atmosphere has caused an increase in average temperature known as the 'greenhouse effect'. Greenhouse effect results in the heating of the earth's surface with a consequential effect on climate changes. Scientists posit that the general rise in average temperature is caused principally by emissions [1]. However, most of these greenhouse gas emissions are caused by human factors. Human activities such as burning fossil fuels (for energy) and deforestation (for agriculture and construction purposes) are the leading cause of climate changes [2]. Yet, as the world shifts its attention to the use of renewables, the combustion of fossil fuels keeps on rising in some countries. As a result of this, climate change keeps worsening because global emissions are galloping. For instance, in 2017, global emissions increased by $1.6 \%$ and 
were projected to reach $2.7 \%$ in 2018 [3]. The increment in global emissions was mostly triggered by emissions from fossil fuels and industrial activities [4]. The gradual shift to an industrial economy with zero climate change action puts the world at risk, hence the need for immediate attention [5]. Against this backdrop, the use of renewable energy sources with improved efficiency and conservation measures are considered instrumental in reducing global emissions [6].

To reduce global emissions, literature depicts that energy conservation [7], energy efficiency [8], coupled with the use of renewables [9] are the key. Energy conservation connotes putting relentless efforts to reduce the consumption of energy by using fewer energy services [10]. Thus, changes in consumption patterns due to the implementation of effective conservation measures reduce cost as well as global emissions [11]. Energy efficiency is achieved when less energy is used in performing the same or similar task that requires more energy [12]. To efficiently utilize energy, energy-efficient electrical equipment and appliances are required in buildings [13]. Another viable option for reducing global emissions is by substituting the use of fossil fuels with a more reliable and safe energy supply from renewables [5]. Renewable sources of energy are projected to be harmless and are naturally replenished [12]. These energy sources are obtained from sunlight (solar energy), wind (wind energy), rain (hydroelectric energy), tides (tidal energy), waves (wave energy), and heat from the earth (geothermal). Renewable energy sources are forecasted to have the capacity to fulfill all of the world's energy demand but, unfortunately, the proportion of its use is highly insignificant especially in some developing and emerging economies [14]. Notwithstanding, the gradual shift to the use of renewable energy sources is gaining roots due to the transition measures signed by the conference of parties in the Paris Agreement. For instance, in 2018, members of the European Union (EU) substituted, on average, $18 \%$ of their total energy demand with renewable energies [15]. As the use of renewable energy sources stems from policy pronouncements on a macro and micro level, policies for utilizing renewable energy in buildings are considered as an initial step in reducing global emissions to a more considerably lower level [10].

According to Yüksek and Karadayi [16], buildings use approximately $40 \%$ of the world's energy. Hinging on energy in buildings, another report [17] estimated that energy used in buildings constitutes approximately $42 \%$ of the world's total energy use. This energy use in different buildings is high because, as household buildings are powered to provide enough energy for heating, cooling, and use electrical appliances [18], industrial buildings are powered to enhance production and other commercial activities. It is worth noting that the choice of energy used in buildings may vary depending on the availability of energy source, affordability, and energy preference measures. Nonetheless, it is recommended that in order to contribute to reversing climate changes, buildings must be designed to be energy efficient [19]. As energy in buildings is used for heating and cooling, ventilation, lighting, etc. to reduce energy consumption in buildings, there must be efforts to design buildings that have good natural aeration and ventilation, good natural lighting, with effective and efficient heating/cooling systems. For instance, using a transparent roof made from fiber-reinforced glass ensures the passage of light rays into buildings serving as a more efficient system to light up buildings, hence calling for retrofits in many buildings [20].

Thermal comfort is one of the most important issues for both residential and commercial buildings. Out of the $40 \%$ of global energy consumed by buildings, a large fraction is used to maintain thermal comfort [21]. Energy used in achieving thermal comfort (heating, lighting, and cooling) in buildings accounts for $28 \%$ of global $\mathrm{CO}_{2}$ emissions [22]. Retrofitting existing buildings presents an opportunity for emission reduction as well as energy conservation/efficiency. Studies in literature have highlighted the importance of building retrofits. Biswas et al. [23], presented a whole building retrofit using energy performance analysis and vacuum insulation panels. Based on their model, a significant reduction in annual energy consumption was achieved in retrofitted buildings as compared to baseline buildings [23]. A new model to enhance retrofit decisions for residential build- 
ings was presented by Uidir et al. [24]. The simulation of nine distinct building archetypes with a sample size of 700,000 households presented an additional $86 \%$ energy efficiency gains. The implementation of different policies has been very instrumental in the reduction of energy consumption in buildings. China as a country has about 191 policies documented for building retrofit [25].

Retrofitting ensures the addition of technologies that can improve energy efficiency and reduce emissions [26]. Yet, the major obstacle with retrofitting is the level of complexities and disruptions involved. Irrespective of the complexities involved in retrofitting, it should be encouraged due to its environmental friendliness coupled with its benefit of proposing a more efficient method to optimize energy in less efficient buildings [26]. In this research, the retrofit of the heating, cooling, and hot water system for an entire community building in Cyprus is presented.

The energy efficiency directive (EED) implemented by the European Union (EU) in 2012 was updated in 2018. This directive was amended to headline a 32.5\% minimum energy efficiency target for 2030. The EED identified existing building stock as the biggest potential for energy savings [27]. A comprehensive review of the recent advancements in building energy conservation and efficiency application is first presented based on existing high-quality research papers. Recently published studies about energy efficiency, energy conservation, and renewable energy applications in buildings are reviewed in order to highlight the recent developments in this field of study. This review will also help researchers understand the state of the art in building energy research and applications. The study aims to analyze the technical and environmental benefits of replacing existing electric heaters with heat pump systems for hot waters. The community considered in this study comprises single-bedroom, double-bedroom, and triple bedroom apartments for both commercial and residential purposes. A total of 88 residential and commercial apartments (including a big administrative building and a restaurant) are retrofitted in this study. Although the use of heat pumps for retrofit purposes have been presented [28,29], however, the estimation is based on the theoretical coefficient of performance (COP) of the systems. In this study, the techno-enviro-economic analysis will be based on the seasonally adjusted COP (SCOP). In comparison to existing kinds of literature, the present study will provide a comprehensive analysis of a community, identify the most economically feasible means of saving energy, and implement the identified retrofit measures. The economic feasibility of the retrofit will be based on the simple payback period (SPP), internal rate of returns (IRR), net present value (NPV). The carbon emission reduction will be analyzed with reference to \#6 fuel oil which is the most commonly used fuel oil for electricity generation in Cyprus. A comprehensive review of building energy demand, retrofits, energy conversation/efficiency as well as renewable energy integration with buildings is first presented in Sections 2 and 3. The methodology adopted for the retrofitting considered in this study is presented in Section 4. The potency of the retrofitting is discussed in Section 5 based on the results from this study while the conclusion of the entire study is summarized in Section 6.

\section{Overview of Energy Demand in Buildings}

The volume of energy demand in a building depends on several factors. Figure 1 depicts the determinants, uses, sources, and costs of energy for buildings while highlighting the cost of pump-based energy sources. Various researchers have posited several of these factors and can be categorized into building characteristics, socio-demographic characteristics of occupants, the general economic trends, resource availability, regulatory systems, and geography. Salari and Javid [30], in their study, identified socio-economic and demographic characteristics of occupants, characteristics of the building, location of the building, temperature, and energy prices as key determinants of residential energy expenditure. The study reported that large households, with older people, high family income, and a high level of householder education tend to demand an increased amount of energy. They added that buildings in metropolitan areas, with high or low temperatures, 
equally impact the overall energy demand in buildings. Eon et al. [31], Hu et al. [32], Ortega-Izquierdo et al. [33], and Romanach et al. [34], all showed that household and user behavior and building characteristics do affect energy demands in buildings and corresponding efficiencies. Gouveia et al. [35] demonstrated that the environment and location characteristics do affect household energy demand in buildings while O'Leary et al. [36] added that the design configuration of residential buildings also impacts energy demand. O'Leary et al. [36] posited that design configurations in terms of external and internal walls, windows and doors, roof, lower and upper floors, ceiling, and external shading impact the energy performance of residential buildings.

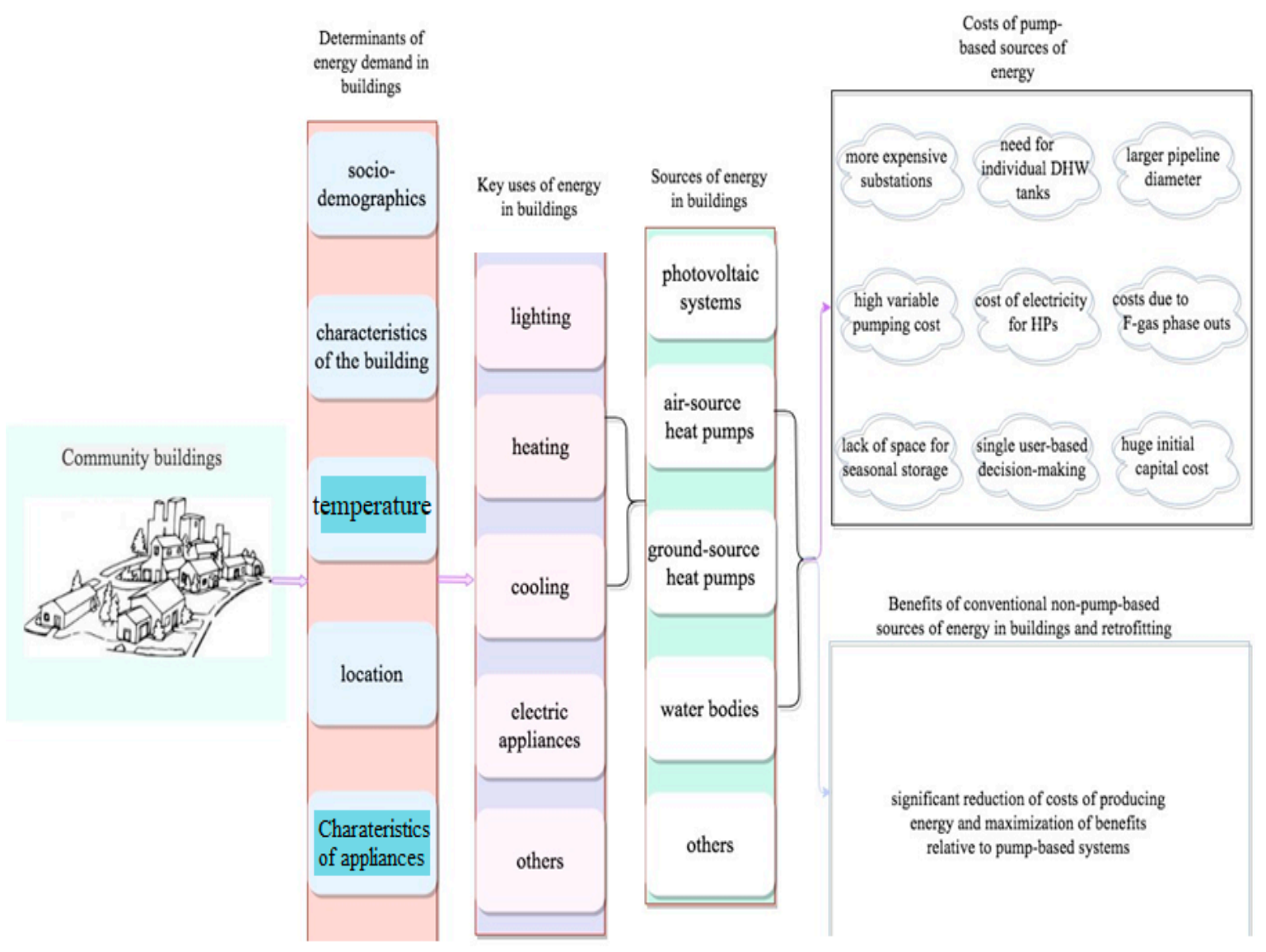

Figure 1. Overview of determinants, sources, costs, and benefits of existing sources of energy for buildings.

There are several sources of energy that serve various purposes in residential buildings. Bee et al. [37] assessed the potential of self-consumption for photovoltaic systems and air-source heat pumps as sources of energy for residential heating and cooling in European climates. They found that variations in energy demand for heating and cooling purposes in the building are explained by variations of properties of the opaque envelope. They observed that though there are some minor differences in seasonal coefficient of performance (SCOP) and seasonal energy efficiency ratio (SEER) of the heat pumps for two types of buildings, it is difficult to assess variations in the SCOP and SEER with different building types since they also depend on the size of the heat pump; which also varies in each case. Buffa et al. [38] investigated about 40 thermal networks that work at a temperature level close to the ground temperature. Their study covered both the heating and cooling loads of buildings in Europe via means of distributed heat pumps (as a source) with installation skewed towards customer substations to propose an unambiguous definition for "Fifth-Generation District Heating and Cooling"(5GDHC networks). They identify ten forms of 5GDHC networks based on some metrics such as the method of heat extraction, number of pipelines, and the combination of the flow direction of energy and 
source. Christodoulides, Aresti, and Florides [39] identified and compared the costs of two sources of energy for buildings; namely, Ground Source Heat Pumps (GSHPs) and Air Source Heat Pumps (ASHPs), for air-conditioning purposes of houses in moderate climates. Hou and Taherian [40] provided an extension of GSHPs and proposed a hybrid system coupling various auxiliary components to the original system to help improve the overall performance. Other studies that proposed hybrid sources of energy systems for the building [41-43] expounded on ground source pump-based sources of energy for heating in residential buildings. They proposed different innovative heat pumps that utilize active magnetic regenerator technology. Li et al. [44] identified "central forced-air heating, ventilation, and air conditioning" (HVAC) as among the commonest systems for conditioning systems in residential buildings. Sayadi et al. [45] performed an extensive dynamic energetic assessment for large complex building cases. Other sources of energy for heating and cooling in residential buildings include thermoelectricity [46].

It is worth noting that each source of energy for heating and cooling purposes in buildings do have advantages and disadvantages, in both economic and non-economic perspectives. Buffa et al. [38] presented several pros and cons of 5GDHC networks. On the positive side, 5GDHC networks allow for recovery of excess heat at low-temperature, exhibit modularity, and resiliency to changes in loads and building-level efficiency results in thermal losses that are trifling can be deployed with pipelines made of polymeric materials and synergizes with seasonal which results in lower losses. On the negative side, 5GDHC networks are more expensive because substations and installations must be made for individual domestic hot water (DHW) tanks, require pipelines with a larger diameter and thermal capacity, results in highly variable pumping costs, require massive space, and is not suitable for direct heating due to the proximity of temperature to the ground temperature. In an attempt to assess GSHPs and ASHPs interchangeability using cost estimates as a yardstick, Christodoulides et al. [39] reported that GSHP systems are not feasible for workable investment towards energy conservation and that ASHP systems which are specifically designed with inverter technology heat pumps are highly competitive. They added that GSHPs require huge initial capital for room and ground loop installations, drilling, piping, fittings, as well as backup heating and cooling systems.

As remedies for pump-based systems, conventional non-pump-based sources of heating and cooling of homes and hot water have been proposed by various researchers. Gerber et al. [47] investigated the use of direct current (DC) as an efficient source of energy for selected appliances (including cooling gadgets such as bath fans, refrigerators) in buildings. They showed that, though direct-DC loads are generally efficient, the efficiency is higher in loads that are unequivocally designed for DC from the ground up relative to an alternating current (AC) modification. The unavoidability of huge costs in providing energy for heating (including hot water) and cooling in the building has made retrofitting a viable option. Ferrante and Semprini [48] iterated that retrofitting constitute light to radical means of improving energy performance in urban buildings. Several studies [49-51] have performed comprehensive analyses on retrofit as an emerging and cost-efficient approach to fulfilling energy demand in buildings. Most of these studies used buildings in Europe as case studies; however, they did not consider the specific application proposed in this study (the replacement of existing electric heaters with heat pump systems for cooling/heating and hot waters).

\subsection{Brief History of Global Energy Consumption in Buildings}

Growth in the world's population has a direct impact on energy consumption in buildings. Maslow's need theory posits that the need for shelter/accommodation is important and it is one of the basic needs that every rational human being seeks to satisfy in their endeavor to achieve their life ambitions [52]. Therefore, each member of the human population requires an accommodation in the form of buildings. When these buildings are erected, the next possible thing that individuals demand is energy to regulate life activities within such buildings. As far as the human population continues to increase, energy consumption 
in buildings surges [12]. However, Share [53] claims that the construction of buildings uses $36 \%$ of global energy and accounts for 39\% of carbon dioxide emissions. Although efforts are being channeled to more sustainable building systems, the pace in attaining a more efficient energy-driven and sustainable building has not been adequate to fulfill the changing need of building energy demand. Therefore, to achieve global building energy sustainability targets, energy efficiency/conservation in buildings must improve on an average of $30 \%$ by 2030 [54].

Showing a more recent trend in global energy consumption in buildings, a report [55] indicated that energy use by buildings rose from 119 exajoules (EJ) in 2010 to about $125 \mathrm{EJ}$ in 2016. Final energy use in buildings grew from 2820 million tonnes of oil equivalent (Mtoe) in 2010 to around 3060 Mtoe in 2018, while the share of fossil fuels decreased only slightly, from $38 \%$ in 2010 to $36 \%$ in 2018 [53]. The speed of energy intensity reductions in the buildings sector has fallen in recent years, from around $2 \%$ in 2015 to an estimated low of $0.6 \%$ in 2018-which is significantly less than the floor area increases of $2.5 \%$ from 2017 to 2018. However, the good news is that emissions in buildings globally reached a peak of 9.5 gigatonnes of $\mathrm{CO}_{2}$ in 2013 and decreased to 9.0 gigatonnes in 2016 [55]. According to this report [55], such reduction was a result of progress made in reducing carbon intensity. The argument is that the world has not been able to achieve minimum greenhouse gas emissions in buildings because the energy and emissions optimization techniques have not been fully utilized [56]. This is due to the continued use of less efficient technologies with zero stringent policies to enforce building regulations. As energy use in buildings is also affected by human factors, some countries have already started to promote occupantfriendly technologies and building attributes that could enable energy savings. A typical example is the use of human factors in building codes in China. In the United States and Canada, there is documentation of best practices for building design and construction available [57]. Many countries in the European Union have legislation in place for these issues as well [58]. More occupant-friendly technologies in buildings take the form of good building orientations and designs amongst the others.

\subsection{Role of Building Orientation, Wall Design, and Fenestration Details on Energy Consumption in Buildings}

Building orientation, wall design, and fenestration details are known to affect energy use in buildings [59]. Typically, the positioning of a building and the use of different material for the building construction is an integral part of energy demand/supply in buildings. It is claimed that the most optimized building orientation with regards to directions is when buildings face south-southwest (north hemisphere) and vice-versa [60]. It is estimated that about $4 \%$ of energy could be lost/gained depending on the orientation of buildings [60]. A similar study asserts that, when building orientation is south-west facing (between $60^{\circ}$ to $75^{\circ}$ ), it receives maximum solar energy for heating demands but if it is north-east facing (between $255^{\circ}$ to $270^{\circ}$ ) it achieves minimum cooling demand [61]. Therefore, to achieve optimal orientation for a building with minimum heating and cooling demands, the main façade should be north facing (between $165^{\circ}$ to $195^{\circ}$ ). Building orientation is one of the most important factors affecting energy consumption [62]. An air-conditioned building that has a southern facade consumes less energy and a western facade causes higher annual energy consumption by $26 \%$ over the southern façade [62]. In terms of a two-facade building, the lowest energy consumption is obtained between the northern and southern orientations [62]. Therefore, building orientation must be considered as crucial during the initial stages of building construction because the orientation can determine the amount of daylight and natural ventilation entering the building thereby, affecting the consumption of energy in buildings. Total energy consumption increases when the window-wall ratio increases [63]. It becomes more significant as the window orientation is east or west. To ensure high energy efficiency, low-emissivity glass is preferable to hollow glass (double glazing) [63]. The influence and sensitivity of the window-wall ratio on total energy consumption are related to the operation mode of the air conditioning system, the orientation of the outside window, and the glazing types of windows [63]. 
However, the design and orientation of buildings can impact energy conservation and efficiency levels and the problem has been to find the most energy-efficient form adaptable to different buildings. The difficulty in attaining the optimal energy-efficient form-aspect ratio has emanated various responses to building orientations. For instance, Koranteng and Abaitey [64] argued that for optimal form-aspect ratio, a detailed functional method of spaces in designing schemes by applying simulation for design alternatives should be applied.

\subsection{Energy Conservation in Buildings}

One way of conserving energy in buildings is the use of insulation. Well-installed insulation ensures energy efficiency in every part of the building envelope including ground decks, roof lofts, walls, and facades [65]. Insulation could be applied in both cold regions and hot ones. In cold/cool regions, insulations act to keep buildings warm and reduce the potential amount of energy that is needed for heating, whereas in hot/warm regions, insulation systems keep the heat out and reduce the need for air conditioning. The shape of buildings influences energy use in buildings [66]. When buildings are compact, it reduces the surfaces in contact with the exterior, thus the building and its openings are given an appropriate orientation (preferably towards the south) and this promotes energy conservation. Leakages can cause either heat loss or heat gain and either of these can affect energy conservation in buildings. The infiltration of cold outside air may result in cold droughts occurring within the building [67]. In the same way, exfiltration can cause heat loss and energy waste through the leakage of warm air.

Additionally, the direction of windows influences energy conservation. Windows facing the east and west have a greater impact on the energy consumption of bedrooms [68]. Therefore, they should either be avoided, or the window-wall ratio must be limited. External windows with suitable shading coefficients should be used. It is also recommended that, to ensure energy conservation design in buildings, the windows of bedrooms should be at the north or south facade with appropriate ventilation, natural lighting, and heating systems. Studies $[69,70]$ indicate that the use of passive solar heating, passive cooling, natural ventilation flow, and daylight can be a good way of maximization of natural energy gains and can result in a significant reduction of delivered energy required to meet a building's energy needs. Therefore, environmentally smart buildings make good use of energy resources, while minimizing waste. Another way of ensuring natural energy gains is by capitalizing the potential contribution of a building's performance offered by its surroundings. To be able to tap impending benefits, the shapes of buildings must enable the flow of daylight and natural ventilation and reduce heat losses [71]. In summary, to increase energy conservation, natural ventilation should be considered wherever practical and appropriate and must be combined with mechanical ventilation or air conditioning. There must be good levels of thermal insulation and prevention of unwanted air infiltration through the building envelope. This is buttressed with intrinsically efficient and well-controlled building services, well-matched to the building fabric and its expected use [17].

\subsection{Energy Efficiency in Buildings}

Energy efficiency concepts measure a building's energy efficiency performance against standard benchmarks measured considering the standards of a given country [72]. Building energy efficiency is determined by several factors including; the degree of electrification, the level of urbanization, the amount of building area per capita, the prevailing climate, as well as national and local policies to promote energy efficiency [17]. Recently, energy efficiency in buildings has received much research attention as studies indicated that it can influence economic growth and improved living standards [20,72]. The energy efficiency of a building highly depends on the building's ability to; reduce heating demand, reduce cooling demand, reduce energy requirements for ventilation, reduce energy use for lighting, heating water, and also reduce the energy consumption of equipment and 
appliances. According to Simona et al. [73], ensuring efficiency in energy use is a step in the right direction to enhance the fight against climate change. However, most of the buildings in the world today do not meet energy efficiency standards and hence need retrofitting [74].

To achieve the required level of energy efficiency in buildings, there is a need for regulations and enforcement. As a result, the USA has adopted energy codes and regulations that are estimated to save more than 14.8 exajoules of energy between 2009 and 2030, with annual savings of 1.8 exajoules in 2030 [59]. In monetary terms, the codes are expected to save the USA more than USD 15 billion in annual savings on energy bills in 2030. Aside from its monetary benefits, it is projected to help reduce pollution and achieve carbon emissions targets [59]. Additionally, to ensure energy efficiency in buildings, the EU mandated its members to obey minimum energy performance requirements for both new and existing buildings undergoing a major renovation. The directive requires building energy performance certificates (EPCs) when a property is sold or leased. For HVAC systems specifically, the directive requires either mandatory inspections of large boilers, air-conditioning plants, and heating systems older than 15 years of age; or advice on the efficient use and replacement of these systems.

\subsection{Renewable Energy Integration in Buildings}

Renewable energy does not emit any form of greenhouse gas and does not cause any form of pollution. Most importantly, investing in renewable energy technologies contribute to economic development and job creation, and environmental improvement [75]. Due to its advantages, renewable energy is considered to be the best substitute for fossil fuel to achieve environmental sustainability targets [76]. This makes it essential for buildings to integrate renewable energy sources (solar, wind, biogas, geothermal, biomass, hydroelectricity as well as wave and tidal power). The integration of renewable energy in buildings has the potential to complement energy-efficient designs of high-performance new buildings by reducing the energy requirements from conventional technologies. Buildings should be designed with a low energy demand, which is met by renewable energy sources. For instance, India's model building bylaws from 2016 conforms to the requirement of integrating renewable energy specifically solar in buildings [77].

On a statistical scale, the projections from the global status report in 2017 indicate that about $18 \%$ of global final energy consumption in 2016 came from renewables, with 13\% coming from traditional biomass, such as wood-burning. Hydropower was the next largest renewable source providing 3\%. Modern technologies such as geothermal, wind, solar, and ocean energy together provided as little as $0.8 \%$ of final energy consumption [78]. According to this statistical report, it is worth noting that renewable energy integration cannot be done effectively without a corresponding advancement in technologies. Currently, the technologies commonly used are; Solar PV, solar thermal, solar ventilation preheating systems, geothermal techniques, wind resources, and bioenergy [78]. To integrate renewable energy technologies in buildings, well-planned design, and energy-efficient technologies must be deployed and assessed at every stage of the building construction project. The renewable energy integration process starts by assessing renewable energy options. This is followed by screening, renewable energy feasibility studies, and size and design systems. When this is carried out appropriately, it ensures that the right renewable energy options are used with the best available technologies. This optimizes the integration process for the best result.

\section{Review of Research on Building Retrofits}

Buildings face functional and maintenance issues in retrofitting and the same applies to renovation and demolishing [79]. Another concern is that for retrofitting, environmental, social, and technical issues are often examined separately in the decision process. Yet, retrofitting presents an opportunity to reduce energy waste and curb air pollution and global warming $[20,79]$. Initially, there were long lists of inefficient all-glass curtain walls, promoted due to retrofitting. Those all-glass curtain wall buildings rely on artificial 
ventilation, cooling, and heating, and suffer from poor insulation, which collectively makes them energy hogs. Recent developments in building retrofitting have made it possible to increase energy efficiency, optimize building performance, increase tenants' satisfaction, and boost economic return while reducing greenhouse gas emissions [74]. In the United States retrofitting is projected to offer a USD 279 billion investment opportunity [80]. It is also projected that, in the next decade, retrofitting can help the United States save over USD 1 trillion on energy bills and reduce $\mathrm{CO}_{2}$ emissions by 600 million metric tons annually.

In terms of macroeconomic gains, retrofits can lead to the creation of over 3.3 million jobs either directly or indirectly in the USA [80]. In the United Kingdom, the majority of large-scale retrofit projects are conducted through elemental retrofit, which uses one or two retrofit measures with relatively low cost and can generally reduce energy consumption and $\mathrm{CO}_{2}$ emissions by $10 \%$ to $30 \%$ [81]. In China, [20] claims that fabric retrofit could reduce up to $54 \%$ of gas consumption in buildings. This claim is substantively based on transitioning to a less heating demand with an improved building envelop. Furthermore, the study asserted that electricity use can be significantly reduced through installing solar PV to the roof and the south facade above the third floor, with reductions of 82.2 to $90.9 \%$ for highrises, and 168.8 to $179.2 \%$ for mid-rises and multi-buildings. The best retrofitting results can be achieved by applying the highest specification of the 'whole-house' approach, which combines fabric, system, and renewable retrofit measures, with annual $\mathrm{CO}_{2}$ emissions reductions of 75.6 to $80.6 \%$ for high-rises, and 104.7 to $105.2 \%$ for multi-storey and mid-rise buildings [20]. Table 1 presents a summary of studies on building energy efficiencies and conservation. Additionally, recent building energy policies are reviewed and presented in the same table. The materials summarized in this table have been chosen based on their relevance to the field of energy buildings and their qualities. While most of the materials summarized are research papers published in top journals, some reports about building energy efficiency and conservation by reputable global energy organizations are also considered.

From all the reviewed materials, it is clear that building energy efficiency, conservation, and management is a global issue that requires immediate attention. Based on these studies, it can be concluded there is a vast potential for building energy conservation if adequate measures are taken, and if the right policies are implemented. Although different studies have proposed different measures to reduce or conserve energy in buildings, there is still a need for researchers to develop other models to solve this same issue. Additionally, the implementation of the existing models and methodologies is required in different parts of the world to validate their adaptability to different buildings and climates. In this study, the use of walk-through energy audit method is used to identify the retrofit measures required to save energy in a community in one of the Mediterranean islands. The details of the retrofit measures and the results are presented in subsequent sections (Sections 4 and 5). 
Table 1. Summary of studies for energy efficiency, conservation, and policies in buildings for the last decade.

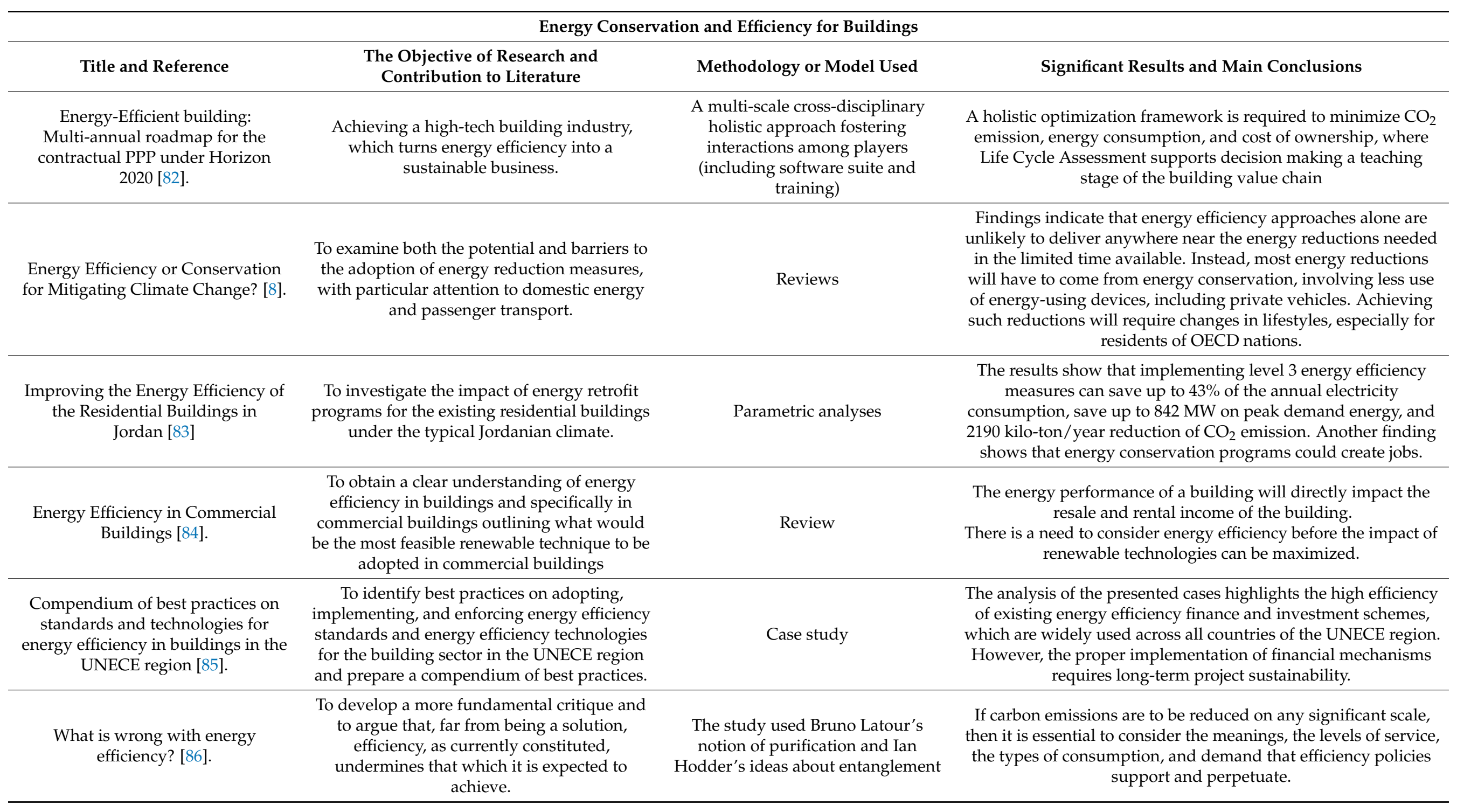


Table 1. Cont.

Energy Conservation and Efficiency for Buildings

\section{Title and Reference}

The Objective of Research and Contribution to Literature
Methodology or Model Used

\section{Significant Results and Main Conclusions}

The GMS countries envisage substantial energy efficiency savings over the next 15-20 years, with Thailand projected to score the highest savings, ranging from 20 to $40 \%$, in its industry and transport sectors.

For Cambodia, the Lao PDR, and Myanmar, the residential and commercial sectors are expected to be the major source of

Energy efficiency targets and developments in five countries in the Greater Mekong Energy efficiency developments an potential energy savings in the Greater Mekong sub-region [87]. Democratic Republic (Lao PDR), Myanmar, Thailand, and Vietnam

Review in the industrial sector.

The national energy efficiency action plans of the five countries identify energy efficiency savings potential in the 30-50\% range for energy-intensive industries, such as the glass, cement, and steel industries.

Overall energy efficiency savings for the five countries could amount to almost 60 million tons of oil equivalent (Mtoe) yearly by 2030 .

Energy is an important production factor and therefore should be managed in parallel with land, labor, and capital. Energy utilization in Nigeria is far from efficient.

Forest and woodland reserves are being depleted for heating and cooking purposes using stoves of efficiency less than $10 \%$

Energy Efficiency and Conservation Measures: Tools for Sustainable Energy Development in Nigeria [88]

To assess possible ways to efficient energy utilization and conservation measures for sustainable energy development in economic sectors in Nigeria.
Review

The oil extraction process includes a lot of waste in the form of spillage resulting in serious environmental problems.

Continuous flaring of large volumes of natural gas in the oil fields of the Niger Delta is worsening the energy supply situation.

Inefficient electrical appliances (lighting, refrigeration, air conditioning, motors, fans, etc), especially in the residential, commercial, and industrial sectors in the face of inadequate supply has aggravated the demand-supply energy imbalance.

Significant progress has recently been made towards the development of simulation workflows to estimate overall operational building energy use across neighborhoods. Given the insight that one may gain from such simulations for planning, design, and policy decisions, the required effort level

to set up and run such models seems justifiable.
Urban building energy modelingreview of a nascent field. [89]
Review of emerging simulation methods and implement workflows for such bottom-up urban building energy models (UBEM).
Thermal modeling 
Table 1. Cont.

\section{Recent energy policies in buildings}

\section{Title and Reference}

Objective of research and contribution to literature

\section{Methodology or model used}

\section{Significant results and main conclusions}

The level of progress on energy regulation activities in Africa, Latin America, and the Middle East is increasing given the

higher number of energy standard proposals recorded in these regions.

Investigates the progress of building energy regulations in developing countries and its implication for energy conservation and efficiency.
A review of building energy regulation and policy for energy conservation in developing countries [10]
Online Survey

Developing countries are still far behind in building energy regulation development, implementation, and compliance when compared to developed nations.

Also, decision making regarding energy regulations is still from the government only, with little or no input from non-governmental entities.

There is lower energy regulation development recorded in these regions compared to regions with integrated and consensus approach.

To facilitate the exchange of expertise and technology on renewable energy between

Renewable energy policy review, Identification of Gaps, and Solutions in Ghana [90].

China and Ghana, with a focus on building the institutional framework and capacity required to facilitate the local absorption of the technologies.

Highlights how the transport sector could be decarbonized and what role Finland's

Energy policies of IEA countries: Finland 2018 review [91] mestic wood-based biofuels could play in it.

Suggest how Finland could maintain

Review energy-efficient combined heat and power $(\mathrm{CHP})$ production

New and Renewable Energy Policy in Developing Indonesia's National Energy Resilience [92].
Discuss new and renewable energy policies as an effort to build national energy security.
Ghana also shows some commitment to overcome the remaining development and deployment.

Energy systems should have the ability to respond promptly and flexibly to energy emergencies. In some cases, this requires collective mechanisms and action

The environmentally sustainable provision and use of energy are central to the achievement of these shared goals.

More environmentally acceptable energy sources need to be encouraged and developed.

The use of new energy and renewable energy as an effort to

build national energy security in Indonesia is still not optimal.

The policy on the use of new and renewable energy aims to

prepare the carrying capacity of national energy security. barriers needed for the accelerated growth in renewable energy 
Table 1. Cont

\section{Recent energy policies in buildings}

\section{Title and Reference}

Building Energy Efficiency: Policy,

learning, and technology change

[93].

Analyses the role of policy instruments and policy packages in the development of energy-efficient end-use building technologies and their emerging markets
To address energy issues (reliability, accessibility, and security) in Cameroon and bring to light the potential and meaningful contributions of renewables in solving energy concerns.

\section{Methodology or model used}

Innovation theory

simely, long-term, and flexible policy support.

The research also highlights the importance of policy support for learning processes in the innovation system and as a determinant of technology change.

The energy sector of Cameroon holds promising possibilities for development and diversification gave the country's energy

potential. With adequate policy, standards, regulations,

Energy policies in Cameroon: holistic overview [94].
Review . investment measures, it is possible for Cameroon to meet future energy targets and ensure meaningful development throughout the country. 


\section{Methodology}

In this study, the retrofit of a community in Cyprus is presented. This section will describe the step taken during this retrofit and presents the economic model used. The emission constants used for environmental analysis will be highlighted.

\subsection{Retrofit Process and Data Collection}

This retrofit focused mainly on the heating, cooling, and hot water system within the housing stock. The general architectural plan/layout for this community is presented in Figure 2. The community consists of both residential and commercial apartments. It also has a central building (housing for administration offices) and a restaurant. The residential apartment consists of 30 units of 2-bedroom apartments and 20 units of 3bedroom apartments. The commercial apartment (hotel) consists of 16 units of 2-bedroom apartments and 20 units of 1-bedroom apartments. The commercial apartments are mostly occupied by tourists who are on a long-term vacation in the country.

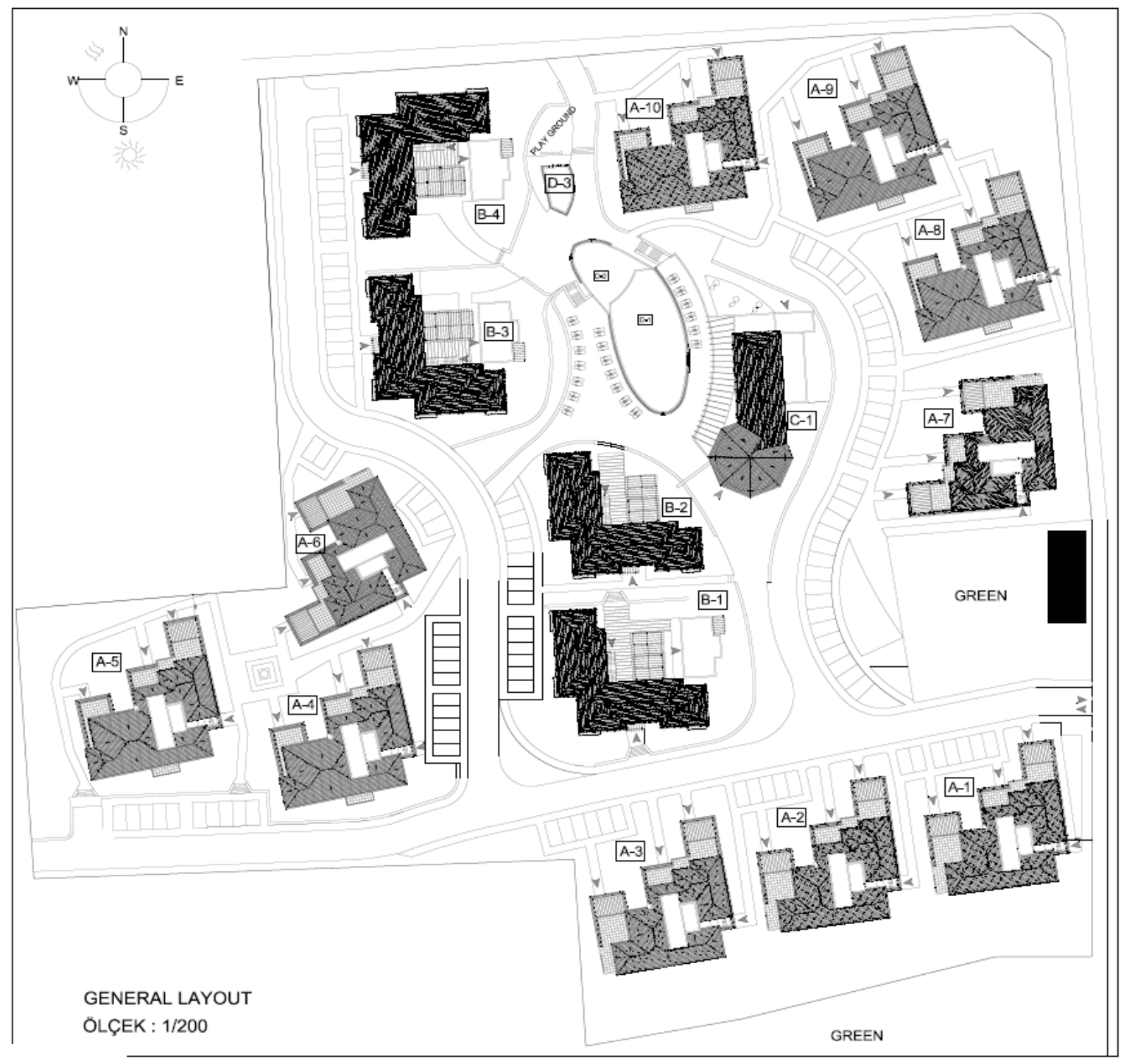

Figure 2. Community Architectural Plan/Layout.

The flow chart of the retrofit process is shown in Figure 3. These processes (Figure 3) are used to determine the retrofit measures suitable for different buildings. Additionally, based on the flow chart, buildings that over-consume energy and do not fit into any retrofit measure should be demolished except if it is for some significant purpose (e.g., ancient 
landmark, tourist attraction, monuments, etc.). Based on the pre-retrofit survey conducted, the use of electric heaters for hot water production, ordinary resistance electrical heaters for space heating, and air-conditioning systems for cooling were identified as the three main energy-consuming units. This is estimated to consume a sizeable amount of energy (Table 2) for each of the buildings thereby, resulting in high overall energy consumption in the community. The goal of the retrofit is to reduce the energy consumption of these buildings. A walkthrough and data-based energy audit is conducted.

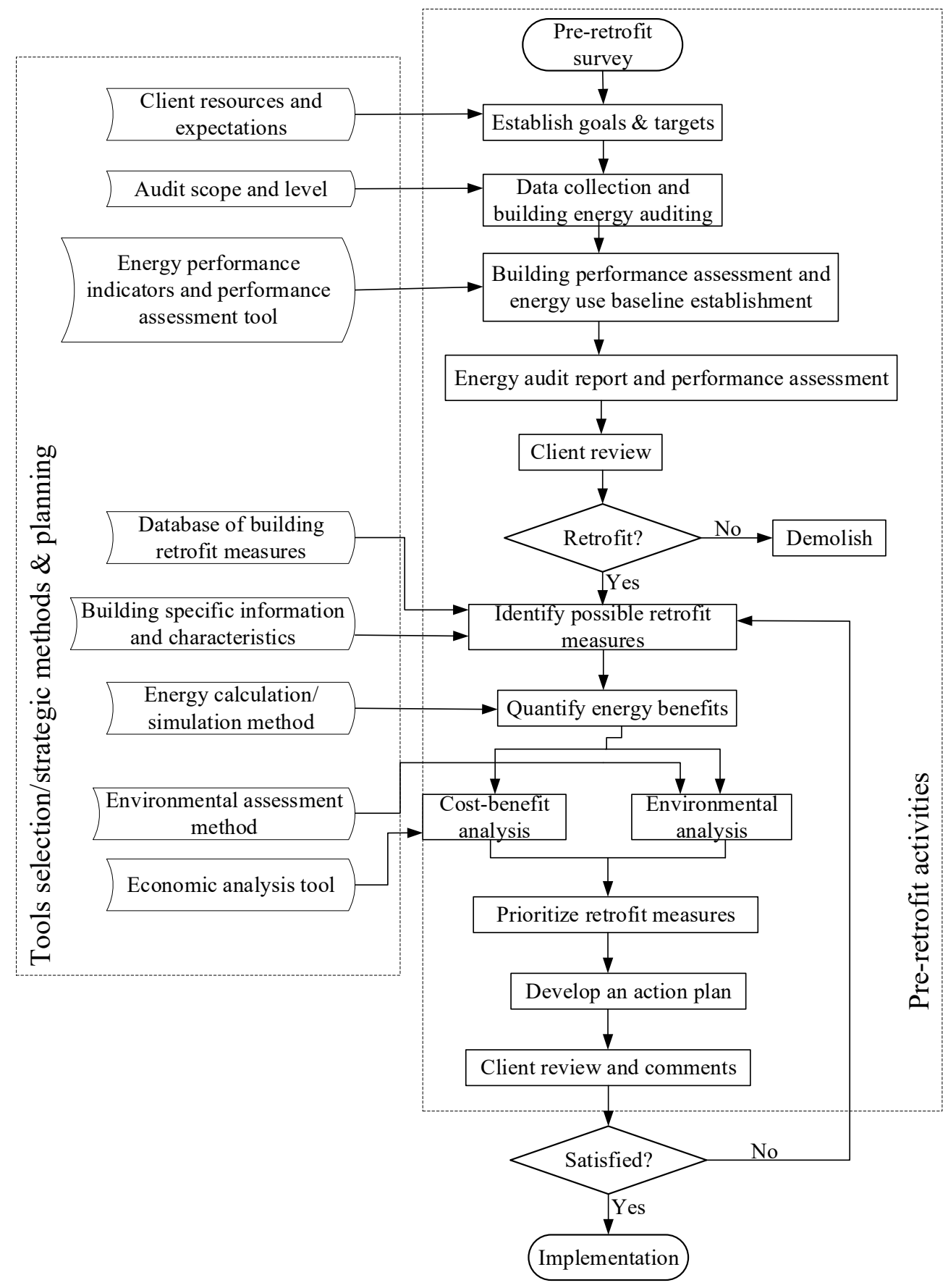

Figure 3. Retrofit Flow Chart. 
Table 2. Hot water and heating/cooling load summary.

\begin{tabular}{|c|c|c|c|c|}
\hline \multicolumn{2}{|c|}{ Type of Apartment } & $\begin{array}{l}\text { Average Number of } \\
\text { Occupants }\end{array}$ & $\begin{array}{c}\text { Hot Water } \\
\text { Consumption (L/yr.) }\end{array}$ & $\begin{array}{c}\text { Area and Average } \\
\text { Heating/Cooling Load }\end{array}$ \\
\hline \multirow{2}{*}{ Residential apartments } & 2-bedrooms & 3 persons & \multirow{4}{*}{$7,533,600$} & 120m²@6 kW each \\
\hline & 3-bedrooms & 4 persons & & $145 \mathrm{~m}^{2} @ 8$ kW each \\
\hline \multirow{2}{*}{$\begin{array}{l}\text { Commercial } \\
\text { apartments }\end{array}$} & 2-bedrooms & 3 persons & & $80 \mathrm{~m}^{2} @ 8$ kW each \\
\hline & 1-bedroom & 2 persons & & $60 \mathrm{~m}^{2} @ 6 \mathrm{~kW}$ each \\
\hline \multirow{2}{*}{ Administrative } & Offices/Restaurant & - & 784,750 & \multirow{2}{*}{$395 m^{2} @ 100$ kW } \\
\hline & Pool shower & - & 375,000 & \\
\hline \multicolumn{2}{|c|}{ Total } & & $8,693,350$ & \\
\hline
\end{tabular}

The hot water consumption is calculated based on the number of occupants in the apartments while the cooling/heating requirements are based on the total area of each of the apartments. The data collected via the audit process is summarized in Table 2. The average hot water consumption for each occupant in the apartments (both residential and commercial) is $80 \mathrm{~L} /$ day. The restaurant serves an average of 300 meals/day and each meal requires an average of $6 \mathrm{~L}$ of hot water. The hot water consumption by the restaurant and administrative staff is estimated to be $350 \mathrm{~L}$ on average. The community also has a general swimming pool for the guests residing in the commercial apartments with an attached shower. Based on the data collected, this shower consumes $2500 \mathrm{~L} /$ day of hot water and the pool is only available during the summer season. The office/restaurant area that required conditioning is $395 \mathrm{~m}^{2}$ and this requires an average of $100 \mathrm{~kW}$ of heating/cooling load.

The existing hot water systems are 20 units of an 80-L electrical boiler, 46 units of 100-L electric boiler, 20 units of 120-L electric boiler, and a 1000-L gas heated boiler. The existing cooling and heating equipment in these apartments are about 15 years old. They have a COP and EER value of 2.8 and 2.65 , respectively. The electrical energy cost $(0.15 € / \mathrm{kWh})$ for this area is the same for both commercial and residential buildings. After the data collection and building energy auditing stage, the energy use baseline and building performance assessment were carried out. This indicates that there will be a significant reduction in energy consumption if the retrofit process is carried out. Based on client review, the retrofit process was approved.

\subsection{Cost-Benefit Analysis}

In the subsection, the models used to determine the cost benefits of this research are presented. The economic analysis is based on the simple payback period (SPP) of the project, the net present value (NPV), and the internal rate of return (IRR). These indicators have been widely used in many existing studies to determine the viability of a project and will serve as economic indicators for the retrofit project in this study. RETScreen energy modeling software is used to perform the economic analysis and the mathematical modeling for these economic indicators are presented in Equations (1)-(3):

$$
\begin{gathered}
S P P=\frac{\text { Total Initial Investment }}{\text { Total annual revenue } \times \text { Total Life Span }} \\
N P V=\sum_{t=1}^{n} \frac{R_{t}}{(1+i)^{t}} \\
0=N P V=\sum_{n=1}^{N} \frac{C F_{t}}{(1+I R R)^{n}}
\end{gathered}
$$

where:

$R_{t}=$ Net cash inflow-outflows during a single period $t$ 
$i=$ Discount rate or return that could be earned in alternative investments

$t=$ Number of timer periods

$C F=$ Initial investment/Outlay

$N=$ Holding period

$n=$ each period

IRR is defined in terms of NPV as it involves the ratio of initial investment to the outlay over a period of time as well as considering the holding period. Holding period return is calculated on the basis of the total returns from the asset or income plus change in value.

\subsection{Environmental Analysis}

The fuel oil used for electricity production in Cyprus is \#6 and this will be used for the emission analysis in the study. The emission factor for this fuel oil is presented in Table 3.

Table 3. Emission Factor table [95].

\begin{tabular}{ccc}
\hline \multirow{3}{*}{ \#6 fuel oil emission factor } & $\mathrm{CO}_{2}$ & $0.263 \mathrm{~kg} / \mathrm{kWh}$ \\
\cline { 2 - 3 } & $\mathrm{NO}_{X}$ & $0.000743 \mathrm{~kg} / \mathrm{kWh}$ \\
\cline { 2 - 3 } Fossil fuel reductions & $\mathrm{SO}_{X}$ & $0.00147 \mathrm{~kg} / \mathrm{kWh}$ \\
\cline { 2 - 3 } & Coal & $0.477 \mathrm{~kg}$ \\
\cline { 2 - 3 } & Natural Gas & $0.286 \mathrm{~m}^{3}$ \\
\cline { 2 - 3 } & Petroleum & $0.276 \mathrm{~L}$ \\
\hline
\end{tabular}

Additionally, the fossil fuel savings (considering a 33\% overall conversion efficiency) of the retrofit measures were calculated considering coal, petroleum, and natural gas energy types. The emission values used for this analysis presented in this study are also summarized in Table 3.

\section{Results and Discussions}

In this research, a comprehensive review of energy conservation measures in buildings has been presented. Additionally, the retrofit of a community that consists of 86 (residential and commercial) apartments as well as an administrative building and a restaurant in Cyprus have been analyzed. Hot water and heating/cooling system energy consumption was identified as the prime opportunity to reduce the energy consumption by the building. A summary of the results from the building energy retrofit is presented in Table 4 .

From the data collected, the daily hot water consumption is $22,000 \mathrm{~L}$ and this will consume an electrical energy equivalent to $1023 \mathrm{kWh} /$ day. The gas consumption for the hot water requirement (considering a calorific value of $50,000 \mathrm{~kJ} / \mathrm{kg}$ and $90 \%$ combustion efficiency) is $81 \mathrm{~kg} /$ day. The proposed heat pump system has a SCOP of 4.5. Based on the annual hot water requirements (Table 2), the proposed units for the apartments are 30 self-contained heat pump boiler 200-L units (for apartments with 2 bedrooms), 10 selfcontained heat pump boiler 300-L unit (for apartments with 3 bedrooms), 4-sets (1000-L boiler + air to water heat pump) for hotel apartments, and 1 unit (2000-L boiler + air to water heat pump) for the administrative building. The maximum temperature for the hot water is set to $50^{\circ} \mathrm{C}$.

The annual energy required to meet this demand is $404,342 \mathrm{kWh} / \mathrm{yr}$. This comprises the total electrical and gas energy consumption by the existing system which is $350,400 \mathrm{kWh} / \mathrm{yr}$ and $53,941 \mathrm{kWh} / \mathrm{yr}$, respectively. The heat pump system will consume $86,836 \mathrm{kWh} / \mathrm{yr}$ to produce the same amount of hot water (Table 4). The total running cost (which includes the energy cost and maintenance) for the existing system is $61,033 € / \mathrm{yr}$. The initial investment and operation/maintenance costs for the proposed heat pump system are $142,000 € / \mathrm{yr}$ and $20,578 € / \mathrm{yr}$, respectively (Table 4). Based on the economic 
analysis, the SPP for this project is 3.58 years. This is highly feasible considering that the heat pumps have a lifespan of 15 years.

Table 4. Hot water and heating/cooling retrofit summary.

\begin{tabular}{|c|c|c|c|}
\hline \multicolumn{2}{|r|}{ Parameters } & Hot Water System & Heating/Cooling System \\
\hline \multicolumn{2}{|c|}{ Existing system running cost $(€ / y r)$} & 61,033 & 55,063 \\
\hline \multirow{2}{*}{ New System } & Replacement cost $(€)$ & 142,000 & 123,500 \\
\hline & Running cost $(€ / y r)$ & 20,578 & 33,339 \\
\hline \multicolumn{2}{|c|}{ Difference in running cost $(€ / y r)$} & 40,455 & 21,724 \\
\hline \multirow{2}{*}{ Existing system } & Electrical energy consumption (kWh/yr) & 350,400 & 367,087 \\
\hline & Gas energy consumption (kWh/yr) & 53,941 & - \\
\hline \multicolumn{2}{|c|}{ New system energy consumption (kWh/yr) } & 86,836 & 222,262 \\
\hline \multirow{2}{*}{ Energy saved (kWh/yr) } & Electrical & 263,564 & 144,825 \\
\hline & Gas & 53,941 & - \\
\hline \multicolumn{2}{|c|}{ Simple payback period (years) } & 3.58 & 5.68 \\
\hline \multicolumn{2}{|c|}{ Internal rate of return $(\%)$} & 24 & 11 \\
\hline \multicolumn{2}{|c|}{ Net present value $(€)$} & 170,089 & 26,951 \\
\hline
\end{tabular}

For the heating/cooling retrofit, an inverter type heating/cooling (reverse cycle) air conditioning $(\mathrm{AC})$ unit is proposed to replace the old AC units. The new system will cost $125 €$ per kilowatt cooling capacity on average. The cooling/heating requirement of these apartments have been highlighted in Table 2. Based on the cooling/heating requirement, the total replacement cost is EUR 123,500 (Table 4). The existing AC units have COP and EER values of 2.8 and 2.65, respectively, and the salvage market value of these systems is equivalent to $10 \%$ of the new systems. The new inverter units have a SCOP of 4.6 and SEER of 4.4, respectively.

Based on data collected the heating degree days (with base temperature $=17^{\circ} \mathrm{C}$ ) of Cyprus is 389 while the cooling degree days (with base temperature $=26^{\circ} \mathrm{C}$ ) is 288 . The design conditions used for energy consumption, respectively, are: $20^{\circ} \mathrm{C}$ indoor, $2{ }^{\circ} \mathrm{C}$ outdoor for winter and $24^{\circ} \mathrm{C}$ indoor, $38^{\circ} \mathrm{C}$ outdoor for summer. The heating and cooling requirements based on these conditions are $512,443 \mathrm{kWh} / \mathrm{yr}$ and $487,790 \mathrm{kWh} / \mathrm{yr}$, respectively. The replacement and running costs for the new proposed system are EUR 123,500 and $33,339 € / \mathrm{yr}$. The $S P P$ for this projected is 5.68 years and this is very good considering that these systems have a 15-20 years lifespan.

One of the main aims of this study is to reduce building energy consumption. The electrical energy required by the hot water systems and the heating/cooling system is reduced by $263,564 \mathrm{kWh} / \mathrm{yr}$ and $144,825 \mathrm{kWh} / \mathrm{yr}$, respectively. Additionally, about $53,941 \mathrm{kWh} / \mathrm{yr}$ of gas is saved from being used for hot water production through the retrofit project (Table 4). Furthermore, considering a discount rate of $8 \%$, the IRR for the hot water system and heating/cooling system replacements are 24 and $11 \%$, respectively. A project is said to be feasible if the IRR is greater than the discount rate; therefore, this retrofit is economically viable. Likewise, the positive NPV (EUR 170,089 for hot water system retrofit and EUR 26,951 for heating/cooling system retrofit) further justifies the economic feasibility of the proposed retrofit project.

The environmental benefit of this retrofit project is enormous considering the importance of reducing carbon emission. The retrofit project will reduce Cyprus $\mathrm{CO}_{2}$ by $121,592.8 \mathrm{~kg}$ yearly (Figure 4). The natural gas and petroleum equivalence, respectively, for the project are; $90,806,430 \mathrm{~m}^{3}$ and $87631.38 \mathrm{~L}$ for hot water system retrofit, 414,199,550 $\mathrm{m}^{3}$ and 39,971.7 $\mathrm{L}$ for air conditioning system retrofit. The $\mathrm{NO}_{\mathrm{x}}$ and $\mathrm{SO}_{\mathrm{x}}$ saved are also highlighted in Figure 4. 


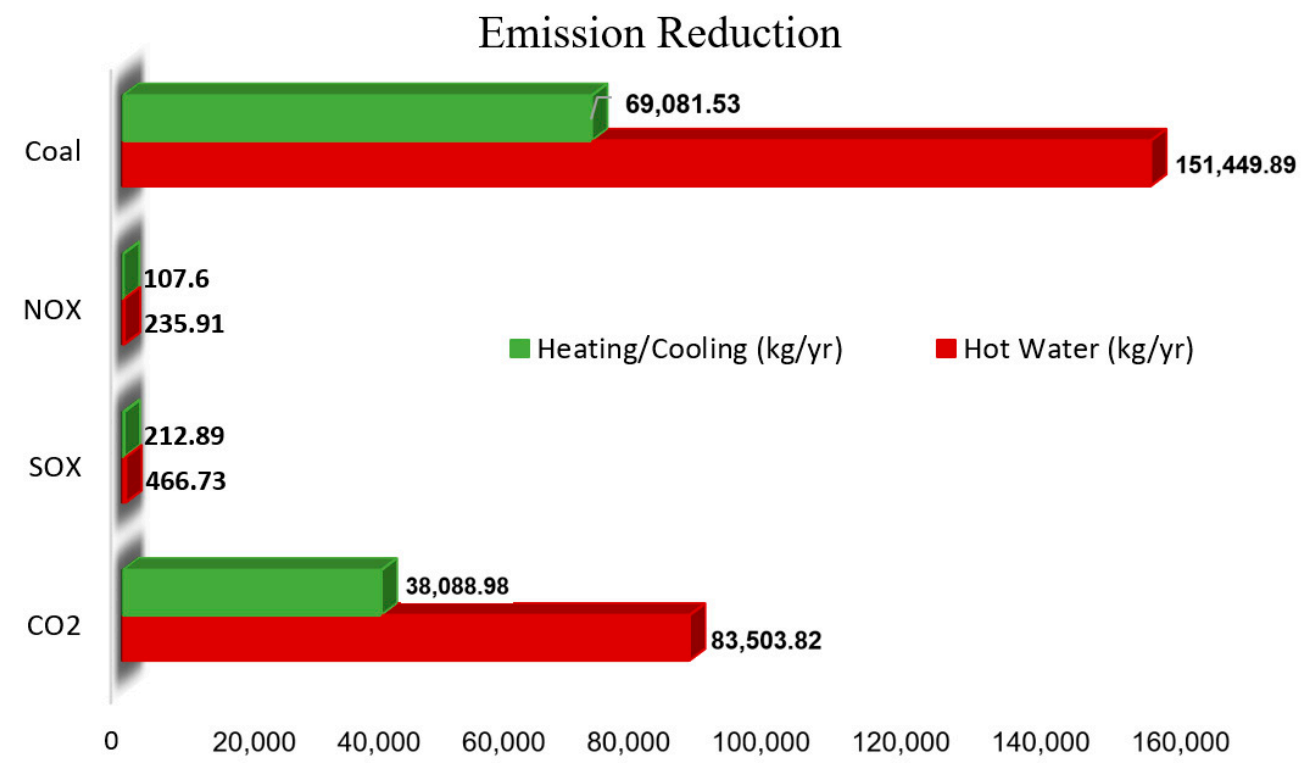

Figure 4. Retrofit carbon emission reduction.

\section{Conclusions}

In the paper, recent studies on building energy efficiency, conservation, policies, and renewable energy application in buildings have been reviewed and presented. Additionally, the importance of retrofitting buildings in order to reduce buildings' energy demands are highlighted. Furthermore, the retrofit of 86 apartments and an administrative/restaurant building was carried out and the analysis is presented in this study. This retrofit only focused on the heating/cooling system and the hot water system of the apartment buildings. The use of heat pump systems to replace the commonly used electric water heaters has been considered for hot water production while inverter type heating/cooling (reverse cycle) systems are proposed to replace the old-style AC units.

From the result of the analysis, the hot water and heating/cooling systems of the apartments were found to be the two main energy-consuming elements. The retrofit of these systems will save a sizeable amount of energy and reduce the building's overall energy demand. As much as 408,389 kWh/yr of electrical energy and 53,941 kWh/yr equivalent of gas supply can be saved by adopting the retrofit measures presented in this study. Based on the economic results of the retrofit study (3.58 years $S P P, 24 \% I R R$, and EUR 170,089 NPV for the hot water system retrofit; 5.68 years $S P P, 11 \%$ IRR, and EUR $26,951 N P V$ for the heating/cooling system retrofit), it can be concluded that the retrofit project is very viable. The environmental analysis in terms of carbon emission reduction further justifies the importance of the proposed retrofit project. In future studies, the proposed retrofit methodology will be applied to other building types like hospital and school buildings.

Author Contributions: Conceptualization, M.M., B.A., O.B. and M.D.; methodology, M.M., B.A., O.B. and M.D.; software, M.M., B.A., N.Y., Q.Z., O.B., H.A., and M.D.; validation, M.M., B.A., N.Y., Q.Z., O.B., H.A., and M.D.; formal analysis, M.M., B.A., N.Y., Q.Z., O.B., H.A., and M.D.; investigation, M.M., B.A., N.Y., Q.Z., O.B., H.A., and M.D.; resources, M.M., B.A., N.Y., Q.Z., O.B., H.A., and M.D.; data curation, M.M., B.A., N.Y., Q.Z., O.B., H.A., and M.D.; writing-original draft preparation, M.M., B.A., N.Y., Q.Z., O.B., H.A., and M.D.; writing-review and editing M.M., B.A., N.Y., Q.Z., O.B., H.A., and M.D.; visualization, M.M., Q.Z., O.B., and M.D.; supervision, O.B., and M.D.; All authors have read and agreed to the published version of the manuscript.

Funding: This research received no external funding.

Institutional Review Board Statement: Not applicable.

Informed Consent Statement: Not applicable. 
Data Availability Statement: Data available on appropriate request to the corresponding author.

Conflicts of Interest: The author declares no conflict of interest.

\section{References}

1. Latake, P.T.; Pawar, P.; Ranveer, A.C. The Greenhouse Effect and Its Impacts on Environment. Int. J. Innov. Res. Creat. Technol. 2015, 1, 333-337.

2. Perera, F.P. Pollution from Fossil-Fuel Combustion is the Leading Environmental Threat to Global Pediatric Health and Equity: Solutions Exist. Int. J. Environ. Res. Public Heal. 2017, 15, 16. [CrossRef]

3. Facility, D.; Blending, P.L.; Manufacturer, C.B. Allergen Free-Pioneers. 2020, pp. 1-8. Available online: https://facilityexecutive. com/2018/04/ten-companies-named-new-energy-pioneers / (accessed on 18 January 2021).

4. Ameyaw, B.; Li, Y.; Oppong, A.; Agyeman, J.K. Investigating, forecasting and proposing emission mitigation pathways for CO2 emissions from fossil fuel combustion only: A case study of selected countries. Energy Policy 2019, 130, 7-21. [CrossRef]

5. Sivaramanan, S. Global Warming and Climate change, causes, impacts and mitigation. ResearchGate 2015, 1. [CrossRef]

6. Ameyaw, B.; Li, Y. Sectoral Energy Demand Forecasting under an Assumption-Free Data-Driven Technique. Sustainability 2018, 10, 2348. [CrossRef]

7. EMF. EMF Report 25 Volume I Energy Efficiency and Climate Change Mitigation. 2011, Volume I. Available online: https: //emf.stanford.edu/publications/emf-25-energy-efficiency-and-climate-change-mitigation (accessed on 18 January 2021).

8. Moriarty, P.; Honnery, D. Energy Efficiency or Conservation for Mitigating Climate Change? Energies 2019, 12, 3543. [CrossRef]

9. Evans, A.L.; Strezov, V.; Evans, T.J. Assessment of sustainability indicators for renewable energy technologies. Renew. Sustain. Energy Rev. 2009, 13, 1082-1088. [CrossRef]

10. Iwaro, J.; Mwasha, A. A review of building energy regulation and policy for energy conservation in developing countries. Energy Policy 2010, 38, 7744-7755. [CrossRef]

11. Van Ettinger, J. Oceans, Climate Change, and Energy. Ocean Yearb. Online 1993, 10, 132-146. [CrossRef]

12. Lo, K. A critical review of China's rapidly developing renewable energy and energy efficiency policies. Renew. Sustain. Energy Rev. 2014, 29, 508-516. [CrossRef]

13. Dubois, M.-C.; Bisegna, F.; Gentile, N.; Knoop, M.; Matusiak, B.; Osterhaus, W.; Tetri, E. Retrofitting the Electric Lighting and Daylighting Systems to Reduce Energy Use in Buildings: A Literature Review. Energy Res. J. 2015, 6, 25-41. [CrossRef]

14. Ben Jebli, M.; Ben Youssef, S.; Ozturk, I. The Role of Renewable Energy Consumption and Trade: Environmental Kuznets Curve Analysis for Sub-Saharan Africa Countries. Afr. Dev. Rev. 2015, 27, 288-300. [CrossRef]

15. European Environmental Agency, Renewable energy in Europe-recent growth and knock-on effects. 2016. Available online: https:/ / www.eea.europa.eu/publications / renewable-energy-in-europe-2016 (accessed on 18 January 2021).

16. Yüksek, I.; Karadayi, T.T. Energy-Efficient Building Design in the Context of Building Life Cycle. Energy Effic. Build. 2017, 1-20. [CrossRef]

17. UNIDO. Sustainable Energy Regulation and Policy-Making for Africa. Management 2011. [CrossRef]

18. Rosin, A.; Moller, T.; Lehtla, M.; Hoimoja, H. Analysis of Household Electricity Consumption Patterns and Economy of Water Heating Shifting and Saving Bulbs. Sci. J. Riga Tech. Univ. Power Electr. Eng. 2010, 26, 15-20. [CrossRef]

19. Ahmad, A.; Hassan, M.Y.; Abdullah, M.; Rahman, H.; Hussin, F.A.; Abdullah, H.; Saidur, R. A review on applications of ANN and SVM for building electrical energy consumption forecasting. Renew. Sustain. Energy Rev. 2014, 33, 102-109. [CrossRef]

20. Rabani, M.; Madessa, H.B.; Nord, N. A state-of-art review of retrofit interventions in buildings towards nearly zero energy level. Energy Procedia 2017, 134, 317-326. [CrossRef]

21. Yang, L.; Yan, H.; Lam, J.C. Thermal comfort and building energy consumption implications-A review. Appl. Energy 2014, 115, 164-173. [CrossRef]

22. Worldgbc. New Report: The building and Construction Sector Can Reach Net Zero Carbon Emissions by World Green Building Council. 2019. Available online: https://www.worldgbc.org/news-media/WorldGBC-embodied-carbon-report-published (accessed on 13 January 2020).

23. Biswas, K.; Patel, T.; Shrestha, S.; Smith, D.; DesJarlais, A. Whole building retrofit using vacuum insulation panels and energy performance analysis. Energy Build. 2019, 203, 109430. [CrossRef]

24. Mac Uidhir, T.; Rogan, F.; Collins, M.; Curtis, J.; Gallachóir, B.P. Ó Improving energy savings from a residential retrofit policy: A new model to inform better retrofit decisions. Energy Build. 2020, 209, 109656. [CrossRef]

25. Liu, G.; Tan, Y.; Li, X. China's policies of building green retrofit: A state-of-the-art overview. Build. Environ. 2020, $169,106554$. [CrossRef]

26. Abdullah, H.K.; Alibaba, H.Z. Retrofits for Energy Efficient Office Buildings: Integration of Optimized Photovoltaics in the Form of Responsive Shading Devices. Sustainability 2017, 9, 2096. [CrossRef]

27. EED. Directive 2012/27/EU of the European Parliament and of the Council of 25 October 2012 on energy efficiency. 2012. Available online: https:/ / eur-lex.europa.eu/eli/dir/2012/27/oj (accessed on 12 December 2019).

28. Asaee, S.R.; Ugursal, V.I.; Beausoleil-Morrison, I. Techno-economic feasibility evaluation of air to water heat pump retrofit in the Canadian housing stock. Appl. Therm. Eng. 2017, 111, 936-949. [CrossRef]

29. Vio, M.; Becchio, C.; Corgnati, S.P.; Crespi, G.; Babuin, M.; Morassutti, S. The Polyvalent heat pumps technology in retrofit of existing HVAC systems. Energy Procedia 2017, 133, 158-170. [CrossRef] 
30. Salari, M.; Javid, R.J. Modeling household energy expenditure in the United States. Renew. Sustain. Energy Rev. 2017, 69, 822-832. [CrossRef]

31. Eon, C.; Morrison, G.M.; Byrne, J. The influence of design and everyday practices on individual heating and cooling behaviour in residential homes. Energy Effic. 2017, 11, 273-293. [CrossRef]

32. Hu, S.; Yan, D.; Guo, S.; Cui, Y.; Dong, B. A survey on energy consumption and energy usage behavior of households and residential building in urban China. Energy Build. 2017, 148, 366-378. [CrossRef]

33. Ortega-Izquierdo, M.; Paredes-Salvador, A.; Montoya-Rasero, C. Analysis of the decision making factors for heating and cooling systems in Spanish households. Renew. Sustain. Energy Rev. 2019, 100, 175-185. [CrossRef]

34. Romanach, L.M.; Hall, N.L.; Meikle, S. Energy consumption in an ageing population: Exploring energy use and behaviour of low-income older Australians. Energy Procedia 2017, 121, 246-253. [CrossRef]

35. Gouveia, J.; Seixas, J.; Mestre, A. Daily electricity consumption profiles from smart meters - Proxies of behavior for space heating and cooling. Energy 2017, 141, 108-122. [CrossRef]

36. Leary, T.O.; Belusko, M.; Whaley, D.; Bruno, F. Comparing the energy performance of Australian houses using NatHERS modelling against measured household energy consumption for heating and cooling. Energy Build. 2016, 119, 173-182. [CrossRef]

37. Bee, E.; Prada, A.; Baggio, P.; Psimopoulos, E. Air-source heat pump and photovoltaic systems for residential heating and cooling: Potential of self-consumption in different European climates. Build. Simul. 2019, 12, 453-463. [CrossRef]

38. Buffa, S.; Cozzini, M.; D'Antoni, M.; Baratieri, M.; Fedrizzi, R. 5th generation district heating and cooling systems: A review of existing cases in Europe. Renew. Sustain. Energy Rev. 2019, 104, 504-522. [CrossRef]

39. Christodoulides, P.; Aresti, L.; Florides, G. Air-conditioning of a typical house in moderate climates with Ground Source Heat Pumps and cost comparison with Air Source Heat Pumps. Appl. Therm. Eng. 2019, 158, 113772. [CrossRef]

40. Hou, G.; Taherian, H. Performance analysis of a hybrid ground source heat pump system integrated with liquid dry cooler. Appl. Therm. Eng. 2019, 159. [CrossRef]

41. Liu, Z.; Li, Y.; Xu, W.; Yin, H.; Gao, J.; Jin, G.; Lun, L.; Jin, G. Performance and feasibility study of hybrid ground source heat pump system assisted with cooling tower for one office building based on one Shanghai case. Energy 2019, 173, 28-37. [CrossRef]

42. Taler, D.; Pitry, R.; Taler, J. Operation assessment of hybrid heat source for heating the building and preparation of hot water in the fire brigade building. J. Clean. Prod. 2019, 214, 962-974. [CrossRef]

43. Johra, H.; Filonenko, K.; Heiselberg, P.; Veje, C.; Dall'Olio, S.; Engelbrecht, K.; Bahl, C. Integration of a magnetocaloric heat pump in an energy flexible residential building. Renew. Energy 2019, 136, 115-126. [CrossRef]

44. Li, T.; Alavy, M.; Siegel, J.A. Measurement of residential HVAC system runtime. Build. Environ. 2019, 150, 99-107. [CrossRef]

45. Sayadi, S.; Tsatsaronis, G.; Morosuk, T. Dynamic exergetic assessment of heating and cooling systems in a complex building. Energy Convers. Manag. 2019, 183, 561-576. [CrossRef]

46. Zuazua-Ros, A.; Martín-Gómez, C.; Ibañez-Puy, E.; Vidaurre-Arbizu, M.; Gelbstein, Y. Investigation of the thermoelectric potential for heating, cooling and ventilation in buildings: Characterization options and applications. Renew. Energy 2019, 131, $229-239$. [CrossRef]

47. Gerber, D.L.; Liou, R.; Brown, R. Energy-saving opportunities of direct-DC loads in buildings. Appl. Energy 2019, 248, 274-287. [CrossRef]

48. Ferrante, A.; Semprini, G. Building energy retrofitting in urban areas. Procedia Eng. 2011, 21, 968-975. [CrossRef]

49. Uriarte, A.; Garai, I.; Ferdinando, A.; Erkoreka, A.; Nicolas, O.; Barreiro, E. Vacuum insulation panels in construction solutions for energy efficient retrofitting of buildings. Two case studies in Spain and Sweden. Energy Build. 2019, 197, 131-139. [CrossRef]

50. Berardi, U.; Soudian, S. Experimental investigation of latent heat thermal energy storage using PCMs with different melting temperatures for building retrofit. Energy Build. 2019, 185, 180-195. [CrossRef]

51. Gabrielli, L.; Ruggeri, A.G. Developing a model for energy retrofit in large building portfolios: Energy assessment, optimization and uncertainty. Energy Build. 2019, 202, 109356. [CrossRef]

52. Liu, X.; Mu, R. Public environmental concern in China: Determinants and variations. Glob. Environ. Chang. 2016, 37, 116-127. [CrossRef]

53. Share, C.C.; Building, O.; Heat, H.; Appliances, C.L. Tracking Buildings. 2020, pp. 1-15. Available online: https://www.iea.org/ reports/tracking-buildings-2020 (accessed on 18 January 2021).

54. Dean, P.; Dulac, B.; Petrichenko, J.; Graham, K. Towards a zero-emission, efficient, and resilient buildings and construction sector. 2016. Available online: https:/ / wedocs.unep.org/handle/20.500.11822/27140 (accessed on 16 January 2021).

55. International Energy Agency. World Energy Outlook. World Energy Outlook 2017 2017. [CrossRef]

56. Knowles, H. Realizing residential building greenhouse gas emissions reductions: The case for a Web-based geospatial building performance and social marketing tool. In Proceedings of the 17th Annual International Emission Inventory Conference: Inventory Evolution-Portal to Improved Air Quality, Portland, Oregon, 2-5 June 2008.

57. Vierra, S. Green Building Standards and Certification Systems. 2019. Available online: https://www.wbdg.org/resources/greenbuilding-standards-and-certification-systems (accessed on 10 December 2019).

58. Fu, F.; Luo, H.; Zhong, H.; Hill, A. Development of a Carbon Emission Calculations System for Optimizing Building Plan Based on the LCA Framework. Math. Probl. Eng. 2014, 2014, 1-13. [CrossRef]

59. Levine, M.; de la Rue de Can, S.; Zheng, N.; Williams, C.; Amann, J.; Staniaszek, D. Building Energy-Efficiency Best Practice Policies and Policy Packages; Lawrence Berkeley National Lab.(LBNL): Berkeley, CA, USA, 2012. 
60. Nalamwar, M.R.; Parbat, D.K.; Singh, D.P. Optimum Building Orientation Study For Central India By Simulation. Int. J. Theor. Appl. Res. Mech. Eng. 2018, 5, 25-27.

61. Ruiz, R.; Bandera, F. Importance of orientation in building energy-savings. In Proceedings of the World Sustainable Building Conference 14, Barcelona, Spain, 28-30 October 2014; 2014; pp. 327-334.

62. Ashmawy, R.E.; Azmy, N.Y. Buildings Orientation and its Impact on the Energy Consumption. Acad. Res. Community Publ. 2018, 2, 35. [CrossRef]

63. Ukwuani, A.; Ahmad, H. In vitro anti-inflammatory activity of Parkia biglobosa fruit bark extract. Int. J. Life-Sci. Sci. Res. 2015, $1,8-11$.

64. Koranteng, C.; Abaitey, E. The Effects of Form and Orientation on Energy Performance of Residential Buildings in Ghana. J. Sci. Technol. (Ghana) 2010, 30, 71-81. [CrossRef]

65. IEA. Technical Synthesis Report: Energy Related Environmental Impact of Buildings; IEA: Paris, France, 2005.

66. Raji, B.; Tenpierik, M.J.; van den Dobbelsteen, A. Early-stage design considerations for the energy-efficiency of high-rise office buildings. Sustainability 2017, 9, 623. [CrossRef]

67. Geletka, V.; Sedlakova, A. Energy consumption conditioned by shapes of buildings. Bud. o zoptymalizowanym potencjale Energ. 2011, 8, 4-11.

68. Grisso, R.; Walker, M.; Energy series. What about house design and room location? Energy. 2020. Available online: https: / /vtechworks.lib.vt.edu/bitstream/handle/10919/97137/BSE-306.pdf?sequence=1\&isAllowed=y (accessed on 16 January 2021).

69. The, I.N.; Design, P. Massing and Building Orientation. Available online: https://knowledge.autodesk.com/support/revitproducts/getting-started/caas/simplecontent/content/building-massing-orientation.html (accessed on 16 January 2021).

70. Jayasinghe, M.T.R.; Sujeewa, L.C.; Fernando, K.K.J.S. Passive solar techniques for sri lanka. 1997. Available online: https://www. researchgate.net/publication/304247421_PASSIVE_SOLAR_TECHNIQUES_FOR_SRI_LANKA (accessed on 16 January 2021).

71. Raof, B. The correlation between building shape and building energy performance. Int. J. Adv. Res. 2017, 5, 552-561. [CrossRef]

72. Ebrahimi, R.; Salehi, M. Investigation of CO2 emission reduction and improving energy use efficiency of button mushroom production using Data Envelopment Analysis. J. Clean. Prod. 2015, 103, 112-119. [CrossRef]

73. Simona, P.L.; Spiru, P.; Ion, I.V. Increasing the energy efficiency of buildings by thermal insulation. Energy Procedia 2017, 128, 393-399. [CrossRef]

74. Al-Kodmany, K. Green Retrofitting Skyscrapers: A Review. Buildings 2014, 4, 683-710. [CrossRef]

75. Yimen, N.; Hamandjoda, O.; Meva'A, L.; Ndzana, B.; Nganhou, J. Analyzing of a Photovoltaic/Wind/Biogas/Pumped-Hydro Off-Grid Hybrid System for Rural Electrification in Sub-Saharan Africa-Case study of Djoundé in Northern Cameroon. Energies 2018, 11, 2644. [CrossRef]

76. Apergis, N.; Payne, J.E. Renewable energy, output, CO2 emissions, and fossil fuel prices in Central America: Evidence from a nonlinear panel smooth transition vector error correction model. Energy Econ. 2014, 42, 226-232. [CrossRef]

77. Chel, A.; Kaushik, G. Renewable energy technologies for sustainable development of energy efficient building. Alex. Eng. J. 2018, 57, 655-669. [CrossRef]

78. Yingrong, C. Renewables in China. Energy Policy 1991, 19, 892-896. [CrossRef]

79. Bu, S.; Shen, G.; Anumba, C.J.; Wong, A.K.; Liang, X. Literature review of green retrofit design for commercial buildings with BIM implication. Smart Sustain. Built Environ. 2015, 4, 188-214. [CrossRef]

80. Baker, J.; Brandenburg, M.; Herbst, R. United States Building Energy Efficiency Retrofits, Market Sizing and Financing Models; Deutsche Bank Climate Change Advisors: Frankfurt, Germany, 2012; p. 50.

81. Brown, D. Business models for residential retrofit in the UK: A critical assessment of five key archetypes. Energy Effic. 2018, 11, 1497-1517. [CrossRef]

82. European Commission. Energy-Efficient Buildings: Multi-annual roadmap for the contractual PPP under Horizon 2020. 2013. Available online: https / / www.buildup.eu/en/practices/publications/energy-efficient-buildings-multi-annual-roadmapcontractual-ppp-under-horiz-0 (accessed on 18 January 2021).

83. Bataineh, K.M.; Alrabee, A. Improving the Energy Efficiency of the Residential Buildings in Jordan. Buildings 2018, 8, 85. [CrossRef]

84. Mulligan, H. Energy Efficiency in Commercial Buildings. CESB 2007 PRAGUE Int. Conf. Cent. Eur. Towar. Sustain. Build. 2007, 1. [CrossRef]

85. UNECE. Joint Task Force on Energy Efficiency Standards in Buildings Mapping of Existing Energy Efficiency Standards and Technologies in Buildings in the UNECE Region. 2018, p. 130. Available online: https://unece.org/fileadmin/DAM/hlm/ Meetings/2018/09_05-07_St._Petersburg/EE_Standards_in_Buildings_full_version.ENG.pdf (accessed on 18 January 2021).

86. Shove, E. What is wrong with energy efficiency? Build. Res. Inf. 2017, 46, 779-789. [CrossRef]

87. ADB. Energy Efficiency Developments and Potential Energy Savings in the Greater Mekong Subregion. 2015.

88. Oyedepo, S.O. Energy Efficiency and Conservation Measures: Tools for Sustainable Energy Development in Nigeria. Int. J. Energy Eng. 2012, 2, 86-98.

89. Reinhart, C.F.; Davila, C.C. Urban building energy modeling-A review of a nascent field. Build. Environ. 2016, 97, 196-202. [CrossRef] 
90. Myers, C.A.; Giphart, J.E.; Laprade, R.F.; Torry, M.R.; Shelburne, K.B.; Woo, S.L.-Y.; Steadman, J.R. In Vivo Tibiofemoral Kinematics During 4 Functional Tasks of Increasing Demand Using Biplane Fluoroscopy. Am. J. Sports Med. 2011, 40, 170-178. [CrossRef] [PubMed]

91. Energy Policies of IEA Countries: Finland 2018 Review; IEA: Parise, France, 2018; Available online: https://webstore.iea.org/ download/summary/2372https:/ / webstore.iea.org/download/summary/2372 (accessed on 16 January 2021).

92. Pinilih, S.A.G.; Chairunnisa, W.L. New and Renewable Energy Policy in Developing Indonesia's National Energy Resilience. E3S Web Conf. 2019, 125, 10004. [CrossRef]

93. Kiss, B. Building Energy Efficiency-Policy, learning and technology change. 2013. Available online: https://www.buildup.eu/ en/practices/publications/building-energy-efficiency-policy-learning-and-technology-change (accessed on 16 January 2020).

94. Muh, E.; Amara, S.; Tabet, F. Sustainable energy policies in Cameroon: A holistic overview. Renew. Sustain. Energy Rev. 2018, 82, 3420-3429. [CrossRef]

95. Bamisile, O.O.; Dagbasi, M.; Abbasoglu, S. Economic feasibility of replacing sodium vapor and high-pressure mercury vapor bulbs with LEDs for street lighting. Energy Policy Res. 2016, 3, 27-31. [CrossRef] 